\title{
Особенности выражения метатекста в лирике Б.Л. Пастернака: аспект номинационно-синтаксического семиозиса
}

\author{
Царева Н.А. \\ Пятигорский государственный университет, \\ Россия, 357532, г. Пятигорск, Ставропольский край, пр. Калинина, 9 \\ E -mail: professorburov@ rambler.ru
}

\begin{abstract}
Аннотация: Несмотря на многочисленные и разносторонние исследования в области русской поэтической картины мира, в филологии все еще отсутствует характеристика метатекстового ракурса осмысления роли автора как языковой личности, организующей пространство поэтического текста. В связи с этим в статье поставлена цель - на материале лирики Б.Л. Пастернака выявить характер авторского метатекстового присутствия, определяющегося антропогенным подходом к поэтическому тексту как производному творческой синергии поэта и окружающего его мира, и задействованием при этом ресурсов синтаксической номинации. В результате анализа употребления синтаксических наименований в пастернаковском тексте доказано, что условия для формирования номинационно-синтаксических единиц возникают благодаря тесноте, сжатию и сукцессивности стихового ряда. Сделан вывод о том, что по мере созревания лирического героя Пастернака наблюдается трансформация соотношения текста и метатекста, вызванная изменениями в проявлении индивидуального мировосприятия. Автором статьи впервые рассмотрен метатекстовый ресурс синтаксической номинации в поэтическом тексте, что вносит вклад в современную лингвистику художественного текста.
\end{abstract}

Ключевые слова: Б.Л. Пастернак, поэтическая картина мира, синергия, метатекст, метатекстовый оператор, синтаксическая номинация, эстетико-эвристическое измерение

Для цитирования: Царева Н.А. 2021. Особенности выражения метатекста в лирике Б.Л. Пастернака: аспект номинационно-синтаксического семиозиса. Вопросы журналистики, педагогики и языкознания, 40 (4): 554-567. DOI: 10.52575/2712-7451-2021-40-4-554-567

\section{Features of Expression of Metatext in Lyrics B.L. Pasternak: Aspect of Nomination-Yntaxic Semiosis}

\author{
Nina A. Tsaryova \\ Pyatigorsk State University, \\ 9 Kalinin St, Pyatigorsk 357532, Russian Federation \\ E -mail: professorburov@ rambler.ru
}

\begin{abstract}
Despite numerous and versatile studies in the field of the Russian poetic picture of the world, philology still lacks a characteristic of the metatext perspective of understanding the role of the author as a linguistic personality organizing the space of a poetic text. In this regard, the author set a goal - based on the lyrics of B.L. Pasternak to reveal the nature of the author's metatext presence, which is determined by an anthropogenic approach to the poetic text as a derivative of the creative synergy of the poet and the world around him, and by using the resources of syntactic nomination. As a result of the analysis of the use of syntactic names in the Pasteur-Nak text, it was proved that the conditions for the formation of nominal-syntactic units arise due to the tightness, compression and successiveness of the verse series. In this case, the poet receives not only complete freedom of choice
\end{abstract}


and the main atri-boutique of the denotation and the circumstances accompanying the disclosure of the signs of the signified, but also the opportunity to create new nominal structures in the space of the text that contain elements of meta-commentary, include subjective-evaluative moments, fix the author's presence in the text. The main metatextual "threads" in a poetic text are intratextual units of syntactic nomination. It is concluded that as the lyrical hero of Pasternak matures, there is a transformation in the ratio of text and metatext caused by changes in the manifestation of individual world perception. The author of the article is the first to consider a metatext resource of syntactic nomination in a poetic text which contributes to modern linguistics of an artistic text.

Key words: B.L. Pasternak, poetic picture of the world, synergy, metatext, metatext operator, syntactic nomination, aesthetic-heuristic dimension

For citation: Tsaryova N.A. 2021. Features of Expression of Metatext in Lyrics B.L. Pasternak: Aspect of Nomination-Yntaxic Semiosis. Issues in Journalism, Education, Linguistics, 40 (4): 554-567 (in Russian). DOI: 10.52575/2712-7451-2021-40-4-554-567

\section{Введение}

Языковая материя находится в непрерывном движении и развитии, и поэтому многие аспекты речевой деятельности неизбежно остаются непознанными. Не выявленные ранее моменты, по мнению Т.М. Николаевой, «могут быть продуктом нового времени, формироваться сейчас. Они могут также быть отпечатком, "следом" былых, почти нейтрализованных, оппозиций. Тогда они связаны с тем, что предлагается назвать "скрытой памятью" языка» [Вербальная и невербальная опоры, с. 7]. Особенно показательно это для языка художественной литературы, в частности поэтического дискурса, который специфичен тем, что «не отображает мир, а, преломляя и интерпретируя поступающую в языковое сознание информацию, становится своеобразным смыслогенерирующим и миропорождающим "устройством", создает собственный мир со своими правилами, ментальный фрагмент "одного из возможных миров"» [Чумак-Жунь 2014, с. 22].

Вскрытие, дешифровка явлений, в которых запечатлены следы «скрытой памяти», во многом определяется характером авторского проявления в тексте, участием индивидуальной языковой личности в превращении потенциальной энергии словаря в кинетическую энергию синтаксиса, когда автор таким образом организует текстовое пространство, что начинает действовать конструктивно-стилевой вектор «беллетристикум» как «постижение в себе то ли сознанием, то ли ощущением строя образов, мыслей, чувств, звуков в такой связи, в какой они до того не связывались никем» [Костомаров 2005, с. 107].

Язык поэтического текста - это «не просто средство технической обработки, но и само бытие, которое надо духовно открыть» [там же, с. 109], выявить веками накапливаемую в нем духовную энергию. Поэт как языковая личность не только создает текст, но и формирует его метатекстовое пространство - авторский комментарий, характеристику, оценку авторского подхода к изображению.

Рассматривая авторский метатекст в поэтическом тексте, необходимо разграничивать термины «метатекст» и «метаязык».

Введя одним из первых в научный обиход термин «метаязык», Р. Якобсон выделил «“объектный язык”, на котором говорят о внешнем мире, и метаязык, на котором говорят о языке» [Якобсон, 1975, с. 201]. Позже о «языке - объекте» и о «метаязыке» как об искусственном языке исследования предмета, зачастую становящемся самим «новым языком - объектом...», писал Р. Барт [1994, с. 131-132]. Метатекст же - понятие, которое, будучи метаязыковым, позволяет рассматривать текст в иной плоскости, обозначая текстовый языковой материал, который «не добавляет что-либо в содержание суждения, но направлен на то, чтобы помочь получателю систематизировать, интерпретировать или оценивать данную информацию» [Hyland, 19]. Метатекстовые элементы текста способ- 
ствуют вербализации авторских интенций, связанных с названием текста, элементами его развертывания и номинацией реализуемых при этом шагов, с выражением отношения к тексту, его адресации и т.д. [Шаймиев, 1999]. Расшифровывая сказанное в тексте, комментируя его, метатекст упрощает понимание его смысла. Однако это естественно в отношении нехудожественной речи и выступает, по мнению исследователей, в качестве «подлинно научного подхода к объекту, пути теоретической абстракции, научного обобщения [Иванов, 2007, с. 43]. В этом плане «целесообразно считать метатекст категорией, которая понимается значительно шире метаязыка» [Иванников, 2017, с. 339]. Так реализуется семантика терминологического компонента мета-, которая «отражает одно из важнейших свойств языка - его рефлексивность, понимаемую как способность языка описывать самое себя» [Гурочкина 2009, с. 52].

Что же касается речи художественной и прежде всего поэтической, то здесь картина иная. «Громадная работа художника над словом имеет конечною целью его преодоление, ибо эстетический объект вырастает на границах слов, границах языка как такового; но это преодоление материала носит чисто имманентный характер, художник освобождается от языка в его лингвистической определенности не через отрицание, а путем имманентного усовершенствования его...» (курсив наш. - Н.Ц.) [Бахтин 1986, с. 68].

Расшифровка «скрытой памяти - это, в частности, выход в авторский текст в поисках его метатекстовых составляющих, позволяющих говорить о метамодальности текста как таком проявлении авторской модальности, которое устанавливает присутствие автора и его позиции в отношении изображаемого: текст как «смысл» соотносится со своим «собеседником»- новым текстом, формируемым автором в базовом тексте, который «оказывается способным к саморазвитию» [Лотман, 2002, с. 67]. Важнейшим условием создания поэтического текста является способность его автора к синергии (греч. бvvєрүía - сотрудничество, содействие, помощь, соучастие, сообщничество) как фактору открытия автором антропогенного ресурса текста и - шире - дискурса в прочессе творческого познания мира (ср. иной подход к понятию синергетичности поэтического текста, основанный на определении самоорганизующихся экзистенциальных смыслов [Муратова 2012]). Раскрывая в лирическом дискурсе свое индивидуальное начало и реализуя метапрагматические установки, языковая личность автора в итоге приходит к открытию для себя и для читателя того нового, что составляет специфику идиостилевой дискурсивности как субъективного, присущего только данному поэту «погружения в жизнь». Синергическое взаимодействие с тем, что вдохновляет поэта на творческую деятельность, сообщает эстетический импульс, ведет его воображение как бы «изнутри», делает процесс создания oткрытием («стихи не пишутся - случаются», по выражению А.А. Вознесенского), и метатекстовые средства - это «ключи» к познанию как приобщению, постижению того, что изначально находится «внутри» творимого текста и чье декодирование имеет ценность как сам процесс постижения творения в момент встречи количеств энергии творческого движения, с одной стороны, уже заложенного генетической исторической памятью, а с другой метакомментария как открытия, обнажения авторского поиска, развертываемого в тексте.

Есть предположение, что при этом закладывается еще и момент памяти предвидящей, опять же на основании метатекстового декодирования, которое раскрывает эстетическое представление автора поэтического слова о мире, смысле его развития и способах его познания в языке, формирует поэтическую картину мира как его образ (В. фон Гумбольдт), выражает предчувствие, предвидение, иногда даже предсказание, пророчество о будущем.

\section{Объект, цель и методы исследования}

Объектом настоящего исследования является поэтический дискурс великого русского художника слова Б.Л. Пастернака, а собственно предметом осмысления - выраже- 
ние метатекста в процессе проявления поэтической синергии автора на антропогенном уровне поэтического дискурса.

Цель работы - на материале пастернаковской лирики зрелого периода творчества выявить характер авторского метатекстового присутствия, определяющегося индивидуальным и имманентным подходом к тексту как производному творческой синергии поэта и окружающего его мира, и задействованием при этом ресурсов синтаксической номинации.

Авторское именование фрагментов картины мира, осуществляемое с помощью производных номинационно-синтаксического семиозиса - синтаксических обозначений различного структурного типа [Буров, 2012], рассматривается нами с учетом их метатекстового употребления не только в отдельном стихотворном тексте, но и в составе поэтического цикла (ПЦ). Для анализа выбраны тексты, наиболее ярко отражающие эволюцию поэтической синергии поэта и, соответственно, характера авторского метакомментирования. Методы исследования пастернаковского текста, вписывающиеся в антропоцентрическую парадигму языка, тем не менее, приобретают, как мы уже отметили, ракурс антропогенности. Ставшее уже привычным мнение, согласно которому познание действительности и его закрепление в языковой картине мира происходит в процессе деятельности человека и утверждения в сознании определенной антропоцентрической системы материальных и духовных ценностей, получающих свое именование, справедливо лишь тогда, когда языковые факты отражают синергию автора и Творца, чей промысел заложен в органике языка и является источником его эстетической энергии. Данный момент определяет ракурс применения автором статьи таких методов исследования поэтического текста Б.Л. Пастернака, как когнитивный, дискурсивный, лингвостилистический, текстологический, номинационно-синтаксический, а также приемов гармонической организации текста и метатекста и другое.

\section{Специфика поэтического метатекста}

В ходе исследования были в основном проанализированы поэтические тексты, созданные Б.Л. Пастернаком ${ }^{1}$ в последние десятилетия творческого пути. Прежде чем характеризовать особенности метатекстовой синергии и способы ее раскрытия, ярко обозначившиеся именно в этот период, определимся с нашим пониманием поэтического метатекста.

Мы рассматриваем поэтический метатекст как особую систему «средств репрезентации присутствия авторской языковой личности в пространстве ею же создаваемого текста» [Буров, 2016, с. 6]. Формируемый личностью автора «метатекстовый интерьер» текста «является результатом не просто авторской организации, но скорее внутренней самоорганизации художника слова, когда активизируются такие "начала", как синергетика, ментальность, идентичность, личностная имманентность и др.» [Буров, 2016, с. 6].

Подчеркнем, что данный подход к изучению метатекста вполне коррелирует с уже сформировавшейся научно-исследовательской традицией, которая развивает идеи А. Вежбицкой, оказавшие существенное воздействие на большинство точек зрения, которые отражают лингвистический ракурс интерпретации рассматриваемого понятия. В частности, это высказанная А. Вежбицкой плодотворная мысль, согласно которой корреляция «язык объект vs метаязык соотносится с оппозицией высказывание о предмете vs высказывание о самом высказывании» [Вежбицкая, 1978, с. 403]. Рассматривая любой текст как двутекст сам текст и комментирующую часть к нему, А. Вежбицкая понимает метатекст как текст в тексте, включающий «слова и выражения, имеющие референтом определенный текст и указывающие на тему высказывания, на связь между фрагментами текста; выявляющие от-

${ }^{1}$ Пастернак Б.Л. 1985. Избранное. В 2-х т. Стихотворения и поэмы. М., Художественная. Литература. 
странение говорящего от своих слов; эксплицитно или имплицитно упоминающие сам процесс речи - это метаорганизаторы и метатекстовые компоненты» [там же].

Эти «метаорганизаторы», по мнению Т.В. Шмелевой, имеют модальную природу и «присутствуют в высказывании незримо, зримое их присутствие - сигнал нарушения стандартов общения» [Шмелева, 1994, с. 27]. Л.А. Савицкая также считает, что эти «метасмыслы» «отражают рефлексию говорящего не над диктумным содержанием, а над самой формой (планом выражения) высказывания» [Савицкая, 2009, с. 347]. Имеется в виду выражение модуса - модальности, присущей метатексту.

Мы считаем, что распространенное в современной лингвистике представление о соотношении метатекста и рефлексива, терминологической единицы, которая «подчеркивает главную, родовую черту метаязыковых образований - наличие языковой рефлексии, направленность языкового сознания на познание самого себя» [Вепрева, 2005, с 77], нуждается в уточнении. Утверждая, что «рефлексив и метатекст соотносятся с языковой рефлексией по-разному», справедливо, если развести сферы действия данных явлений: с одной стороны, это сфера нашего сознания, где возникает, по мнению И.Т. Вепревой, «коммуникативное и когнитивное напряжение в речемыслительной деятелыюсти», вызывающее рефлексию [Вепрева, 2003, с. 6], а с другой - область речевого плана, аспект вербализации языковых рефлексий. В таком случае справедливо и утверждение Е.Б. Иванникова о том, что «рефлексив выражает языковую рефлексию, а метатекст выступает как высказывание о высказывании; следовательно, в метатексте необязательно должна присутствовать только языковая рефлексия» [Иванников, 2017, с. 344]. Действительно, метатекст формирует речевой план языковой рефлексии, и кроме собственно речевых вербализаторов метатекстовую природу могут иметь и невербальные средства языка, в частности интонационные.

Независимо от способов выражения языковой рефлексии в метатексте его употребление связано прежде всего с модусом высказывания - модальностью, присущей метатексту как органической части текста. Г.Я. Солганик справедливо утверждает, что «во всех элементах речи - от слова и словосочетания до текста - субъективная (текстовая) модальность выступает как важнейший компонент образования речи, ее элементов, значения, стиля, тональности» [Солганик, 2010, с. 132]. И.Р. Гальперин подчеркивает, что в лирике субъективно-оценочная характеристика предмета мысли главенствует: «Не будет преувеличением сказать, что поэтические тексты насквозь модальны» [Гальперин, 2008, с 115]. Думается, речь здесь должна идти о проявлении авторской модальности, которая специфична на уровне метатекста и может квалифицироваться как метамодальность. Особый индивидуально-авторский оценочный пласт метатекста коррелирует со своеобразным ограничением концептуального содержания поэтической картины мира и проявлением «особого "фильтра" - метаконцепта Поэтическое» [Маслова, 2011]. Именно это, скорее всего, имел в виду Д.С. Лихачев, когда характеризовал концепт как «не просто алгебраическое выражение, не знак и не символ, а послание (message)» ${ }^{1}$.

Сама гармоническая организация поэтического текста, основанная на определенном ритмомелодическом интонационном рисунке, такова, что способствует предельному обнажению природы номинации как имени. По А.Ф. Лосеву, в имени энергия сущности вещи «достигает своего полного определения. <... ...Имя и есть расцветшее и созревшее сущее. <...> Имя - как максимальное напряжение осмысленного бытия вообще - есть также и основание, сила, цель, творчество и подвиг... всей жизни...» [Лосев, 1999а, с. 152]. Вполне закономерно, что эта сущностная энергия находит для своего выражения в процессе употребления в тексте не только однословную, но и аналитическую, расчлененную форму синтаксической единицы - словосочетания, придаточного, целого высказывания, даже связного текста как производных номинационно-синтаксического семиозиса [Буров 2012].

${ }^{1}$ Лихачев Д.С. 1985. Борис Леонидович Пастернак. В кн.: Пастернак Б.Л. Избранное. В 2-х т. T. 1. Стихотворения и поэмы. М., Художественная литература: 3-28 


\title{
Номинационно-синтаксический ракурс поэтического метатекста Б.Л. Пастернака
}

Поэтический текст Пастернака прекрасно раскрывает эстетическо-энергетический потенциал синтаксической номинации. Само имя денотата, будучи репрезентантом определенного концепта, создает образное представление о нем посредством расчленения его внутренней формы в пространстве синтаксического наименования, когда автору - и в тексте, и в метатексте - открывается атрибутика синергически познаваемого объекта. В самом деле, сравним:

\author{
Из кухни вид. Оконце узкое \\ За занавескою в оборках, \\ И ходики, и утро русское \\ На русских городских задворках.
}

\section{Изолотая червоточина}

На листьях осени горбатой, Иугол, бомбой развороченный, Где лазали его ребята.

(Зарево)

Стандартная модель односоставного номинативного предложения (Из кухни вид), «свертывающего» в пространстве субстантивного именования пропозицию ситуации, при расширении в правом тексте получает постпозитивное уточнение, распространение, за счет латентного позищионного предищирования атрибуции, в виде одного или нескольких атрибутивных признаков (вплоть до предикативного фразового осложнения «где лазали...» в последней конструкции), которые эксплицируют основание номинации, ее внутреннюю форму. Автор за счет синтаксических ресурсов текста формирует номинационные дескрипции, восполняя тем самым словарную недостаточность и решая свои индивидуальные задачи изображения [Буров 2012, с. 148]. Это и есть проявление авторского метатекста, задействующего потенциал структурно-функциональной «пружины» внутренней динамики - в данном случае именного плана, энергии, скорее больше потенциальной, чем кинетической.

Метатекстовые «послания» - комментарии автора в пастернаковском тексте характеризуются разноплановостью, проявляясь как на уровне отдельно взятого стихотворного текста, так и на уровне поэтического цикла. Рассмотрим вначале проявление метатекстовых «нитей», функционирующих в пространстве отдельного лирического произведения поэта.

Мы считаем, что в основании поэтического метода Пастернака лежит не художественное расчленение окружающего мира и рожденных им образов и представлений, а образное восприятие и представление мира таким, каков он есть во всей простоте, естественности, полноте и гармонической целостности его проявлений. Сказанное становится основанием для понимания и языка - объекта поэтического пастернаковского текста, и его метаязыка - авторского метатекста.

Вся сложность - в выборе подхода к поэтической вербализации того, что есть «са́мое само́» [Лосев 1999а] в окружающем мира и его деталях - их сущность, воплощаемая образно как именно пастернаковская. В этом проявляется все: и поэтическая картина мира, и языковая личность, и идиостиль, и соотношение поэтического текста и метатекста. Многомерность Вселенной Пастернака динамична и может опираться прежде всего на экспрессию русского синтаксиса, чей богатейший ресурс сочетаемости и комбинаторики очевиден и позволяет реализовать любые факты словообразования и словоупотребления. Более того, в синтаксическом пространстве отражаются и семиотическая динамика, и син- 
таксичность семантики любой единицы номинации - как однословной, так и аналитической [Гак, 1998]. Метатекст способен представить проекцию семантики, к примеру, концепта, являющегося смысловым и экспрессивным «стержнем» лирического текста.

Думается, для интерпретации подхода к поэтической вербализации того, что есть в пастернаковском идиостиле са́мое самó как именно пастернаковское, вполне применима методика, основанная на номинационно-синтаксическом семиозисе и употреблении единиц синтаксической номинации в тексте. Синтаксическая номинация, на наш взгляд, вполне обладает объяснительной силой в случае с особенностями идиостиля Пастернака, спецификой его языковой личности и поэтической картины мира, с соотношением поэтического текста и метатекста, и др. Главное же, что делает номинационно-синтаксический семиозис прерогативой пастернаковской поэзии, - это специфика авторского понимания номинации и ее внутренней формы, раскрывающейся в атрибуции.

Метатекст раскрывается в тексте, в частности, через атрибуцию как основание, внутреннюю форму номинации. Очевидно, в случае с пастернаковским текстом целесообразно рассматривать атрибуцию не только на уровне отдельного именования и его ближайшего контекста, но и всего поэтического текста и даже на уровне поэтического цикла. В данной статье внимание уделяется метатекстовой функции синтаксической номинации в пределах отдельно взятого лирического текста.

Выражение атрибуции как основы номинации в поэтическом тексте обусловлено характером предицирования признака, лежащего в основании наименования. Сжатие стихового ряда [Тынянов, 1993, с. 87] актуализирует разнообразие способов и характера выражения атрибутивного признака, в частности - характер и способы его предицирования в тексте. Действие «пружин» именования включается благодаря динамическому равновесию стихового ряда и структурно-семантического пространства синтаксической единицы. Вскрываются дополнительные семантические оттенки, не только несущие скрытые смыслы, но и являющиеся собственно авторскими «вкраплениями» метатекстового характера.

Взять, к примеру, фразовую номинацию - одно из наиболее изученных и ярких средств синтаксического обозначения. Будучи основано на гипотаксисе - строгой коррелятно-релятной местоименно-соотносительной модели нерасчлененного подчинения [Максимов 2011, Буров 2012], оно обычно встречается далеко не у каждого автора поэтического текста. Пастернак, особенно в зрелый период творчества, отдает предпочтение простым и сочинительно-бессоюзным конструкциям в целом, что уже само по себе исключает использование фразовой номинации. Одним из редких случаев обращенния поэта к фразовому обозначению встречаем в конце первой строфы стихотворении «Гамлет» (1946):

\section{Гул затих. Я вышел на подмостки. \\ Прислонясь к дверному косяку, \\ Я ловлю в далеком отголоске,}

Что случится на моем веку.

Фразовая номинация (Что случится на моем веку) помогает автору за счет структурно-семантической возможности спроецировать предикативный признак в будущее, сохранить при этом обобщающий характер значения, тем самым расширив «зрительный зал, - по тонкому замечанию И.И. Чумак-Жунь, - до размеров вселенной» [Чумак-Жунь 2006, с. 56]. Возникающая интертекстуальная ассоциация с шекспировским «Весь мир театр, все люди в нем - актеры» формирует метатекстовый план - принципиальную авторскую корреляцию как вектор жизненного пути и автора, и его героя: человек - мир [Чумак-Жунь 2006, с. 56]. 
Сравним еще один из немногочисленных примеров в тексте, датированном 1953 годом:

\author{
Мне далекое время мерещится, \\ Дом на Стороне Петербургской. \\ Дочь степной небогатой помещчицы, \\ Ть - на курсах, ты родом из Курска.$$
<\ldots>
$$ \\ Фонари, точно бабочки газовые, \\ Утро тронуло первою дрожью. \\ То, что тихо тебе я рассказываю, \\ Так на спящие дали похоже. \\ Мы охвачены тою же самою \\ Оробелою верностью тайне, \\ Как раскинувшийся панорамою \\ Петербург за Невою бескрайней.
}

(Белая ночь)

Благодаря предикативной форме фразового обозначения (To, что тихо тебе $\boldsymbol{s}$ paccказываю) автор включает свой метаголос в поэтический диалогический дискурс («mебе я рассказываю»), дает характеристику происходящего («тихо») и обобщает детали разговора лирического героя с героиней («то, что»). Активизируется синтаксическая динамика номинации как предикация атрибутики и спроецировано авторское отношение к синтаксическому пространству номинации семантики сложного концепта (он представлен в названии текста). С завуалированной семантикой перифрастического наименования, рассказываемого «тихо», частично ассоциируется значение правого по отношению к фразовой номинации текста, где говорится об «оробелой верности тайне», которая окутывает белыми ночами Петербург и сближает его панораму с «тихо» звучащими словами лирического героя Пастернака.

Или - еще редкий пример задействования Пастернаком метатекстовго ресурса фразового наименования в тексте стихотворения «Никого не будет в доме»:

\title{
Ть появишься у двери \\ Вчем -то белом, без причуд, \\ В чем -то, впрямь из тех материй, Из которых хлопья шьют.
}

Фразовая номинация, осуществляемая в данном тексте, свидетельствует не только о функционально-прагматической гибкости и динамизме данного типа обозначения, его пластичности, но и об авторском ощущении внутренних динамических ресурсов «дыхания» грамматики текста: в частности, это употребление местоименных «исходов» (Н.Ю. Шведова), местоименной сочетаемости и возникающей на ее основе аппроксимационной описательной номинации «в чем-то белом» и ее синтаксического развертывания в процессе следования за ускользающем мгновением бытия. Уточняющая фразовая номинация (из тех материй, из которых хлопья шьют) насыщена лексикой таинственности и необычности (наряд любимой сшит из чистой «снежной материи»), что способствует передаче состояния зыбкого, нечеткого движения чувств. Динамика снежной стихии - одна из любимых сквозных метатекстовых линий пастернаковскогй поэзии (ср. написанное четверть века спустя «Снег идет» и др.). Являясь ярко выраженным речевым средством номинации, характерным для динамического синтаксиса, фразовое обозначение своим употреблением утверждает принципы витализма, характерные и для отечественной кар- 
тины мира послепушкинской эпохи развития русского литературного языка, и для идиостиля Пастернака.

Метатекстовое употребление фразовой номинация связано с функциональнопрагматической заданностью строгой коррелятно-релятной модели в составе полипредикативной сложноподчиненной структуры нерасчлененного типа [Максимов, 2011]. Гипотаксис, в отличие от паратаксиса, а также асиндетона, предполагает такой путь выражения авторского образного представления о денотате, которое основано на известном структурировании, уточнении, конкретизации как «разрушении» целостности, объемности, масштабности объекта поэтического описания. Как раз это органически не свойственно идиостилю Пастернака, который тяготеет к синтезу, объемности изображения.

Его стихия - насыщение непредикативных словосочетаний скрытой потенциальной предикацией, когда синтаксическая номинация явления рождается прямо в тексте в условиях полнейшей свободы авторского выбора атрибутики внутренней формы и именно с таким расположением топики в цепи элементов пространства номинационносинтаксического отрезка, который соответствует выражению их естественных отношений и связей в изображаемом фрагменте картины мира. Например:

Осень. Сказочныий чертог,

Всем открытый для обзора.

Просеки лесных дорог,

Заглядевшихся в озера.

Как на выставке картин:

Зальы, зальы, зальы, зальь

Вязов, ясеней, осин

В позолоте небывалой.

Липы обруч золотой -

Как венец на новобрачной.

Лик березы - под фатой

Подвенечной и прозрачной.

(Золотая осень)

Номинационно-синтаксический «взгляд» Пастернака в данном контексте основан на стремлении максимально объемно и полно представить рисуемые образы с помощью распространения гибких и емких односоставных номинативных конструкций. Это свидетельствует и о функционально-прагматической гибкости и динамизме данного способа именования как познания мира, и о метатекстовом векторе употребления данных единиц. Авторская репрезентация глубинных, скрытых смыслов при употреблении синтаксической номинации в поэтическом тексте напоминает распрямляющуюся структурносемиотическую «пружину», вскрывающую коммуникативный, когнитивный и экспрессивный потенциал индивидуально ощущаемой картины мира, причем ощущаемой прежде всего в ее именованиях и их атрибуции как основы внутренней формы, включающей и метатекстовый момент.

Следовательно, в отдельном поэтическом тексте метатекстовый ракурс присутствия автора обусловлен конкретными художественно-изобразительными задачами представления определенного денотата и его признаков.

Несколько иная картина наблюдается в пространстве поэтического цикла (ПЦ), когда выражение атрибутивного признака маркировано конкретными изобразительными задачами, решаемыми уже целым текстовым фрагментом как органическим компонентом пространства ряда текстов. В задачи данной статьи характеристика метатекстового 
статуса пастернаковского ПЦ не входит. Заметим только, что в зрелой лирике Пастернака наблюдается трансформация соотношения «текст - метатекст», вызванная изменениями в проявлении индивидуального авторского начала. Это связано с тем, что для пастернаковского творческого метода ПЦ как своеобразная сюитная форма в заключительный период творчества играет роль важнейшего структурно-композиционного средства не только представления собственно картины мира и ее фрагментов, но и пояснения авторского пути ее познания, то есть метакомментария. Это распространяется и на глобальный ракурс индивидуально-авторского миропонимания, и на выражение личного отношения к окружающей поэта советской действительности конца 30-50-х гг. XX века. Текст Пастернака становится его единственным оружием в поединке с целой системой, в то время как метатекст как способ позиционирования автора текста превращается, на наш взгляд, в своеобразный индикатор авторского отношения к современному миру посредством включения в него обобщения глобального философского, нравственного и эстетического опыта многовековой монументальной Человеческой Культуры, в том числе - событий Христианской истории.

Являясь ярко выраженным речевым способом номинации, характерным для динамического синтаксиса, синтаксическая номинация своим употреблением позволяет автору не только представить свой «объемный» взгляд на обозначаемое, но и за счет номинационной сочетаемости направить восприятие текста по пути естественного отражения жизненных процессов, воплощая принципы витализма, характерные и для отечественной картины мира послепушкинской эпохи развития русского литературного языка, и для идиостиля великого поэта.

\section{Заключение}

Б.Л. Пастернак принадлежит к тем уникальным художникам слова, творческая манера которых выделяется на фоне не только их предшественников и современников, но и тех, кто живет и творит после них. Эта «инакость» вместе с тем не есть превознесение себя над другими, какое-то обособление, самоизоляция художника-анахорета. Напротив, это как раз обратное, - А.Ф. Лосев называет это «самостью» - постоянным поиском в окружающем мире и его деталях того, что есть их «са́мое само́», их сущность. «Хорошо видеть са́мое само́ в космосе, в Боге, во всех вещах, взятых как целое, - пишет философ. Но еще лучше не потерять его из вида в вещах мелких, частичных, случайных, временных и никому не интересных. На них-то как раз и выступает с элементарнейшей очевидностью вся простота, но и вся неприступность, вся абсолютность этого са́мого самого́» [Лосев 1999, с. 505].

В основании метода изображения мира в пастернаковской поэзии лежит, как мы считаем, естественная данность гармонии целого, проявляющаяся в самых обыденных явлениях, фактах, предметах, ситуациях, причем в той последовательности, в какой они оказываются в поле зрения авторского восприятия и соответствующего фрагмента поэтической картины мира. Поэтому наиболее приемлем для определения характера идиостиля Пастернака подход с позиций синергии как сотрудничества, соработничества автора и окружающего мира, в нашем случае - поэта и Творца, открывающего только ему лично его - единственный - субъективный, индивидуально ощущаемый и имманентный путь художественного познания мира.

Наши наблюдения показывают, что важную роль в выражении метатекстового плана у Пастернака играет авторское употребление производных номинационносинтаксического семиозиса. Использование когнитивно-дискурсивного потенциала единиц синтаксической номинации отвечает главному принципу изображения действительности в пастернаковской поэзии - образному представлению мира как единого целого. Как мы убедились, идиостиль Пастернака наиболее полно раскрывается с позиций синергии. Использование номинационно-синтаксического способа именования в решении метатекстовых задач как нельзя более полно и адекватно соответствует пастернаковскому вос- 
приятию действительности и формированию в его сознании авторской поэтической картины мира.

Очевидно, однако, и то, что поэтический текст такой многогранной и сложной языковой личности, как Б.Л. Пастернак, предполагает и иные способы и средства раскрытия авторского метатекста, что лишний раз должно свидетельствовать об актуальности эвристического ракурса интерпретации языка высокой поэзии. В.П. Григорьев в свое время выдвинул идею четырехмерного пространства языка, в котором семантика, синтактика и прагматика языка дополняется эвристикой. Как считает этот исследователь, в сфере современных гуманитарных исследований «...речь могла и должна бы идти, без иллюзий и преувеличений, об уверенно назревавшем концептуальном сдвиге к новой парадигме не только в словесном искусстве, но и в лингвистике и филологии - о полноправном признании необходимого всей культуре (ее практикам и теориям) четвертого, так сказать, всеохватывающего и всепроникающего, эстетико-эвристического измерения языка» [Григорьев 2006, с. 676] (ср. близкую точку зрения в работе, в которой аналогичное измерение языкового знака связывается с проявлением «функции речевого мгновения». Считая данное измерение «точечным», автор связывает его с выражением глубинных свойств текста, скорее всего - надтекстового порядка, что требует обязательного рассмотрения его в составе целого - текста [Буров 2003, с. 147]).

Гипотеза эстетико-эвристического измерения поэтического текста предполагает качественную трансформацию слова в особую единицу, функционирующую только в «сильных» поэтических контекстах. Перу Пастернака принадлежат в основном только те тексты, которые В.П. Григорьев относит к «сильным». Внутренняя поэтическая форма пастернаковской лирики полностью соответствует «всеохватывающему и всепроникающему» измерению языка как Откровения великой Языковой Личности.

\section{Список литературы}

1. Барт Р. 1994. Литература и метаязык. Пер. с фр. С.Н. Зенкина. В кн.: Барт Р. Избранные работы: Семиотика. Поэтика. Под ред. Г.К. Косикова. М., Прогресс; Универс: 131-132. (Barthes R. 1964. Essais critiques. P., Seuil: 106-107.)

2. Бахтин М.M. 1986. Проблема содержания, материала и формы в словесном художественном творчестве. В кн.: Бахтин М.М. Литературно-критические статьи. М., Художественная литература: 26-89.

3. Буров А.А. 2003. Когниолингвистические вариации на тему русской языковой картины мира. Пятигорск, Изд-во ПГЛУ, $361 \mathrm{c.}$

4. Буров А.А. 2012. Субстантивная синтаксическая номинация в русском языке. Под ред. К.Э. Штайн. Ставрополь-Пятигорск, Изд -во СГУ, 400 с.

5. Буров А.А. Бурова Г.П. 2016. Метатекстовый интерьер художественного текста. Пятигорск, Изд-во ПГУ, 183 с.

6. Вежбицкая А. 1978. Метатекст в тексте. В кн. Новое в зарубежной лингвистике. Вып. 8: Лингвистика текста. М., Прогресс: 402-421.

7. Вепрева И.Т. 2003. Метаязыковая рефлексия в функционально-типологическом освещении (на материале высказываний-рефлексивов 1991-2002 гг.) Автореф. ... дис. докт. филол. наук. Екатеринбург, 42 с.

8. Вепрева И.Т. 2005. Языковая рефлексия в постсоветскую эпоху. М., ОЛМА-ПРЕСС, 384 с.

9. Вербальная и невербальная опоры пространства межфразовых связей. 2004. Под ред. Т.М. Николаевой. М., Языки славянской культуры, 256 с.

10. Ветошкина 3.А. 2011. Языковые средства реализации субъективной модальности в цикле Б. Л. Пастернака «Стихотворения Юрия Живаго». Культурная жизнь Юга России, 4 (42): $111-115$.

11. Гак В.Г. 1998. Языковые преобразования. М., Школа «Языки русской культуры», 768 с.

12. Гальперин И.Р. 2008. Текст как объект лингвистического исследования. М., УРСС Эдиториал, $144 \mathrm{c.}$ 
13. Григорьев В.П. 2006. Велимир Хлебников в четырехмерном пространстве языка. Избр. работы 1958-2000-е годы. М., Языки славянской культуры, 813 с.

14. Гурочкина А.Г. 2009. Метаязык, метакоммуникация, метатекст (к объему содержания понятий). В кн. Когнитивные исследования языка. Под ред. сер. Е.С. Кубряковой. Вып.У: Исследование познавательных процессов в языке. Сб. науч. тр. Под ред. вып. Н.Н. Болдырева. М., Ин-т языкознания РАН; Тамбов, Издательский Дом ТГУ им. Г.Р. Державина: 52-57.

15. Иванников Е.Б. 2017. Языковая рефлексия: от метатекста к рефлексиву. Проблемы истории, филологии, культуры, 1(55): 337-347. DOI: 10.18503/1992-0431-2017-1-55-337-347

16. Иванов Н.В. 2007. Интертекст - метатекст: культура, дискурс, язык. В кн. Языковые контексты: структура, коммуникация, дискурс. Материалы межвузовской научной конференции по актуальным проблемам языка и коммуникации, г. Москва, 21 июня, 2007 года. М., Книга и бизнес: 43-50.

17. Костомаров В.Г. 2005. Наш язык в действии: Очерки современной русской стилистики. М., Гардарики, 266 с.

18. Лихачев Д.С. 1997. Концептосфера русского языка. В кн.: Русская словесность: от теории словесности к структуре текста: антология. Под ред. В.П. Нерознака. М., Academia: 280-287.

19. Лосев А.Ф. 1999. Самое само. В кн.: Самое само: Сочинения. М., ЭКСМО-Пресс: 423-634.

20. Лотман Ю.М. 2002. Текст в тексте. В кн.: Лотман Ю.М. Статьи по семиотике культуры и искусства. СПб., Академический проект: 58-78.

21. Максимов Л.Ю. 2011. Многомерная классификация сложноподчиненных предложений. Под ред. А.А. Бурова, К.Э. Штайн. Ставрополь - Пятигорск, СГУ, 680 с.

22. Маслова Ж.Н. 2011. Поэтическая картина мира и ее репрезентация в языке. Автореф. дис. ... докт. филол. наук. Тамбов, 44 с.

23. Муратова Е.Ю. 2012. Синергетический анализ поэтического текста. Вестник Российского университета дружбы народов. Серия: Теория языка. Семиотика. Семантика, 2: 5357.

24. Савицкая Л.С. 2009. О приеме зачеркивания как средстве метакатегориальной организации модусной перспективы высказывания (на материале интернет-дневников). Вестник Нижегородского университета им. Н.И. Лобачевского, 6-2: 346-349.

25. Солганик Г.Я. 2010. Очерки модального синтаксиса. М., Флинта, Наука, 136 с.

26. Тынянов Ю.Н. 1993. Проблема стихотворного языка. Вавилон: Вестник молодой литературы, 2 (18): $86-90$.

27. Чумак-Жунь И.И. 2006. Культурный контекст и интерпретация поэтического текста. Русский язык в школе, 2: 54-58.

28. Чумак-Жунь И.И. 2014. Поэтический текст в русском лирическом дискурсе конца XVIII - начала XXI веков. М., Директ-Медиа, 302 с.

29. Шаймиев В.А. 1999. Метадискурсивность научного текста: на материале лингвистических произведений. Автореф. дис. ... докт. филол. наук. СПб., 46 с.

30. Шмелева Т.В. 1994. Семантический синтаксис. Красноярск, Изд-во Красноярского гос. ун -та, $43 \mathrm{c}$.

31. Якобсон Р. 1975. Лингвистика и поэтика. Пер. с англ. А.И. Мельчука. В кн.: Структурализм: «за» и «против». Под ред. Е.Я. Басина, М.Я. Полякова. М., Прогресс: 193-230. (Jakobson R. 1960. Linguistics and Puetics. In: Style in Language. Ed. by Th. A. Sebeol., Cambndge, Institute of Technology).

32. Hyland K. 2005. Metadiscourse: Exploring Interaction in Writing. Bodmin, Continuum International Publishing Group, 240 p.

\section{References}

1. Bart R. 1994. Literatura i metayazyk [Literature and metalanguage]. Per. with fr. S.N. Zenkina. In: Bart R. Izbrannye raboty: Semiotika. Poetika [Selected Works: Semiotics. Poetics]. Ed. G.K. Kosikov. M., Publ. Progress; Univers: 131-132. (Barthes R. 1964. Essais critiques. P., Seuil: 106107) (in France).

2. Bakhtin M.M. 1986 Problema soderzhaniya, materiala i formy v slovesnom khudozhestvennom tvorchestve [The problem of content, material and form in verbal art]. In: Bakhtin M.M. Literaturnokriticheskie stat'i [Literary critical articles]. M., Publ. Khudozhestvennaya literatura: 26-89. 
3. Burov A.A. 2003. Kogniolingvisticheskie variatsii na temu russkoy yazykovoy kartiny mira [Cogniolinguistic Variations on the Russian Language Picture of the World]. Pyatigorsk, Publ. PGLU, $361 \mathrm{p}$.

4. Burov A.A. 2012. Substantivnaya sintaksicheskaya nominatsiya v russkom yazyke [Substantive syntactic nomination in Russian]. Ed. K.E. Shtayn. Stavropol'-Pyatigorsk, Publ. SGU, 400 p.

5. Burov A.A. Burova G.P. 2016. Metatekstovyy inter'er khudozhestvennogo teksta [Metatextual interior of artistic text]. Pyatigorsk, Publ. PGU, 183 p.

6. Vezhbitskaya A. 1978. Metatekst v tekste [Metatext in the text]. In: Novoe v zarubezhnoy lingvistike [New in foreign linguistics]. Iss. 8: Lingvistika teksta [Issue]. M., Publ. Progress: 402-421.

7. Vepreva I.T. 2003. Metayazykovaya refleksiya v funktsional'no-tipologicheskom osveshchenii (na materiale vyskazyvaniy-refleksivov 1991-2002 gg.) [Metalanguage reflection in functional-typological coverage (based on reflexive statements of 1991-2002)]. Abstract. ... dis. doct. philol. sciences. Ekaterinburg, 42 p.

8. Vepreva I.T. 2005. Yazykovaya refleksiya v postsovetskuyu epokhu [Linguistic Reflection in the Post-Soviet Era]. M., Publ. OLMA-PRESS, 384 p.

9. Verbal'naya i neverbal'naya opory prostranstva mezhfrazovykh svyazey [Verbal and nonverbal support of the space of interphrase connections]. 2004. Ed. T.M. Nikolaeva. M., Publ. Yazyki slavyanskoy kul'tury, $256 \mathrm{p}$.

10. Vetoshkina Z.A. 2011. Yazykovye sredstva realizatsii sub"ektivnoy modal'nosti v tsikle B. L. Pasternaka «Stikhotvoreniya Yuriya Zhivago» [Language means of realizing subjective modality in the cycle of BL Pasternak "Poems of Yuri Zhivago"]. Kul'turnaya zhizn' Yuga Rossii, 4 (42): 111-115.

11. Gak V.G. 1998. Yazykovye preobrazovaniya [Language transformations]. M., Publ. Shkola «Yazyki russkoy kul'tury», $768 \mathrm{p}$.

12. Gal'perin I.R. 2008. Tekst kak ob"ekt lingvisticheskogo issledovaniya [Text as an object of linguistic research]. M., Publ. URSS Editorial, 144 p.

13. Grigor'ev V.P. 2006. Velimir Khlebnikov v chetyrekhmernom prostranstve yazyka. Izbr. raboty 1958-2000 -e gody [Velimir Khlebnikov in the four-dimensional space of language. Fav. works 1958-2000s]. M., Publ. Yazyki slavyanskoy kul'tury, 813 p.

14. Gurochkina A.G. 2009. Metayazyk, metakommunikatsiya, metatekst (k ob"emu soderzhaniya ponyatiy) [Metalanguage, metacommunication, metatext (to the scope of the content of concepts)]. In: Kognitivnye issledovaniya yazyka [Cognitive language studies]. Ed. ser. E.S. Kubryakova. Iss. U: Issledovanie poznavatel'nykh protsessov v yazyke [Study of cognitive processes in language]. Sat. scientific. tr. Ed. no. N.N. Boldyrev. M., Publ. In-t yazykoznaniya RAN; Tambov, Publ. Izdatel'skiy Dom TGU im. G.R. Derzhavina: 52-57.

15. Ivannikov E.B. 2017. Language reflexion: from metatext to reflexive. Journal of Historical, Philological and Cultural Studies, 1(55): 337-347 (in Russian). DOI: 10.18503/1992-0431-2017-1-55337-347

16. Ivanov N.V. 2007. Intertekst - metatekst: kul'tura, diskurs, yazyk [Intertext - metatext: culture, discourse, language]. In: Yazykovye konteksty: struktura, kommunikatsiya, diskurs [Language contexts: structure, communication, discourse]. Materialy mezhvuzovskoy nauchnoy konferentsii po aktual'nym problemam yazyka i kommunikatsii, g. Moskva, 21 iyunya, 2007 goda. M., Publ. Kniga i biznes: $43-50$.

17. Kostomarov V.G. 2005. Nash yazyk v deystvii: Ocherki sovremennoy russkoy stilistiki [Our Language in Action: Essays on Contemporary Russian Style]. M., Publ. Gardariki, 266 p.

18. Likhachev D.S. 1997. Kontseptosfera russkogo yazyka. [The concept sphere of the Russian language]. In: Russkaya slovesnost': ot teorii slovesnosti $\mathrm{k}$ strukture teksta: antologiya. [Russian Literature: from the Theory of Literature to the structure of the text: an anthology]. Ed. V.P. Neroznaka. M., Publ. Academia: 280-287.

19. Losev A.F. 1999b. Samoe samo. [The very thing]. M., EHKSMO-Press: 423-634.

20. Lotman YU.M. 2002. Tekst $v$ tekste. [Text within the text]. In: Lotman Y.M. Stat'i po semiotike kul'tury i iskusstva. [Articles on the semiotics of culture and art]. SPb., Publ. Akademicheskii proekt: $58-78$.

21. Maksimov L.Yu. 2011. Mnogomernaya klassifikatsiya slozhnopodchinennykh predlozheniy [Multidimensional classification of complex sentences]. Eds. A.A. Burov, K.E. Shtayn. Stavropol'Pyatigorsk, Publ. SGU, 680 p. 
22. Maslova Zh.N. 2011. Poeticheskaya kartina mira i ee reprezentatsiya v yazyke [Poetic picture of the world and its representation in language]. Abstract dis. ... doct. philol. sciences. Tambov, 44.

23. Muratova E.Yu. 2012. The synergetic analysis of a poetic text. Article one. RUDN journal of language studies, semiotics and semantics, 2: 53 -57 (in Russian).

24. Savitskaya L.S. 2009. Crossing as an organizing tool of modal structure in an utterance (based on online diaries). Vestnik of Lobachevsky University of Nizhni Novgorod, 6-2: 346-349 (in Russian).

25. Solganik G.Ya. 2010. Ocherki modal'nogo sintaksisa [Essays on Modal Syntax]. M., Publ. Flinta, Nauka, $136 \mathrm{p}$.

26. Tynyanov Yu.N. 1993. Problema stikhotvornogo yazyka [The Problem of Poetic Languag]. Vavilon: Vestnik molodoy literatury, 2 (18): 86-90.

27. Chumak-Zhun' I.I. 2006. Kul'turnyy kontekst i interpretatsiya poeticheskogo teksta [Cultural context and interpretation of the poetic text]. Russian language at school, 2: 54-58.

28. Chumak-ZHun' I.I. 2014. Poeticheskij tekst v russkom liricheskom diskurse konca XVIII nachala XXI vekov [Poetic text in Russian lyric discourse of the late XVIII - early XXI centuries]. M., Direkt-Media, $302 \mathrm{p}$.

29. Shaymiev V.A. 1999. Metadiskursivnost' nauchnogo teksta: na materiale lingvisticheskikh proizvedeniy [Metadiscursiveness of a scientific text: on the material of linguistic works]. Abstract dis. ... doct. philol. sciences. SPb., 46 p.

30. Shmeleva T.V. 1994. Semanticheskiy sintaksis [Semantic Syntax]. Krasnoyarsk, Publ. Krasnoyarskogo gos. un -ta, 43 p.

31. Yakobson R. 1975. Lingvistika i poehtika. [Linguistics and Poetics]. Translated from the English by A.I. Mel'chuk. In: Strukturalizm: «zA» i «protiV». [Structuralism: "for" and "against"]. Ed. E.YA. Basina, M.YA. Polyakova. M., Publ. Progress: 193-230. (Jakobson R. 1960. Linguistics and Puetics. In: Style in Language. Ed. by Th. A. Sebeol., Cambndge, Institute of Technology).

32. Hyland K. 2005. Metadiscourse: Exploring Interaction in Writing. Bodmin, Continuum International Publishing Group, 240 p.

Конфликт интересов: о потенциальном конфликте интересов не сообщалось.

Conflict of interest: no potential conflict of interest related to this article was reported.

\section{ИНФОРМАЦИЯ ОБ АВТОРЕ}

Царева Нина Александровна, аспирант кафедры словесности и педагогических технологий филологического образования Пятигорского государственного университета, г. Пятигорск, Ставропольский край, Россия

\section{INFORMATION ABOUT THE AUTHOR}

Nina A. Tsaryova, Post-graduate student of the Department of Literature and Pedagogical Technology of Philological Education, Pyatigorsk State University, Pyatigorsk, Stavropol Territory, Russia 